\title{
Absence of linkage between chromosome 21 loci and familial amyotrophic lateral sclerosis
}

\author{
Andrew King, Henry Houlden, John Hardy, Russell Lane, Andrew Chancellor, \\ $\mathrm{J}$ de Belleroche
}

Department of
Biochemistry,
Charing Cross and
Westminster Medical
School, London
W6 8RF.
J de Belleroche
A King
Department of
Neurology, Charing
Cross Hospital,
London.
R Lane
Department of
Biochemistry, St
Mary's Hospital
Medical School,
London.
J Hardy
H Houlden
Department of
Clinical
Neurosciences,
Western General
Hospital, Edinburgh
EH4 2XU.
A Chancellor
Correspondence to
Dr de Belleroche.
Received 29 July 1992.
Revised version accepted
22 September 1992.

\begin{abstract}
Familial amyotrophic lateral sclerosis (FALS) has recently been shown to be linked to chromosome 21 markers in a subset of families. However, we were unable to show linkage between FALS and chromosome 21 markers which flank the putative FALS locus in UK families. (f Med Genet 1993;30:318)
\end{abstract}

Recently, linkage has been reported between familial amyotrophic lateral sclerosis (FALS) and chromosome 21 markers in a subset of families. ${ }^{1}$ Multipoint analysis yielded a significant location score $10 \mathrm{cM}$ telomeric to D21S58. However, no significant two point lod scores were obtained. We have investigated whether a similar linkage occurs in FALS cases collected in the UK. In our study, microsatellite polymorphisms were used to ensure a high level of informativity.

At present, we have identified more than 30 UK families with the characteristic features of an autosomal dominant mode of inheritance with DNA available from at least one affected subject. Entry criteria for this study are that at least one member of the family should show typical upper and lower motor neurone signs. Eight families were used which consisted of 13 affected and 35 unaffected subjects. Five microsatellite polymorphisms were investigated which flank the FALS locus identified by Siddique et $a l^{1}$ and are in order from the centromere: D21S120, D21S214, D21S210, $I F N A R$, and D21S156. DNA was amplified by PCR in the presence of ${ }^{32} \mathrm{P} \alpha$-dCTP and primer pairs for the five loci and separated on $6 \%$ polyacrylamide. Two point lod scores were determined using the program MLINK with published allele frequencies (GDB). An age dependent penetrance curve was used ( 0.78 at 80 years).

The lod score table (table) shows significant exclusion of linkage at a recombination fraction of 0.001 for D21S210, D21S214, and IFN $A R$ and a significant exclusion of linkage for $D 21 S 156$ out to a recombination fraction of 0.004 . No significant linkage or exclusion was

Pairwise lod scores between FALS and five chromosome 21 loci.

\begin{tabular}{lrrrrrrrrr}
\hline $\begin{array}{l}\text { Chromosome } \\
\text { location }\end{array}$ & \multicolumn{10}{c}{ Recombination fraction } \\
\cline { 2 - 9 } & 0 & 0.001 & 0.005 & 0.01 & 0.05 & 0.1 & 0.2 & 0.3 & 0.4 \\
\hline D21S214 & -4.79 & -2.00 & -1.31 & -1.01 & -0.39 & -0.18 & -0.04 & -0.01 & 0 \\
D21S210 & -4.72 & -2.20 & -1.51 & -1.22 & -0.58 & -0.35 & -0.17 & -0.1 & -0.05 \\
D21S120 & 0.49 & 0.49 & 0.48 & 0.47 & 0.41 & 0.34 & 0.2 & 0.09 & 0.02 \\
IFNAR & -5.25 & -2.19 & -1.49 & -1.19 & -0.49 & -0.21 & -0.01 & 0.02 & 0.00 \\
D21S156 & -5.63 & -2.56 & -1.86 & -1.55 & -0.82 & -0.5 & -0.22 & -0.08 & -0.02 \\
\hline
\end{tabular}

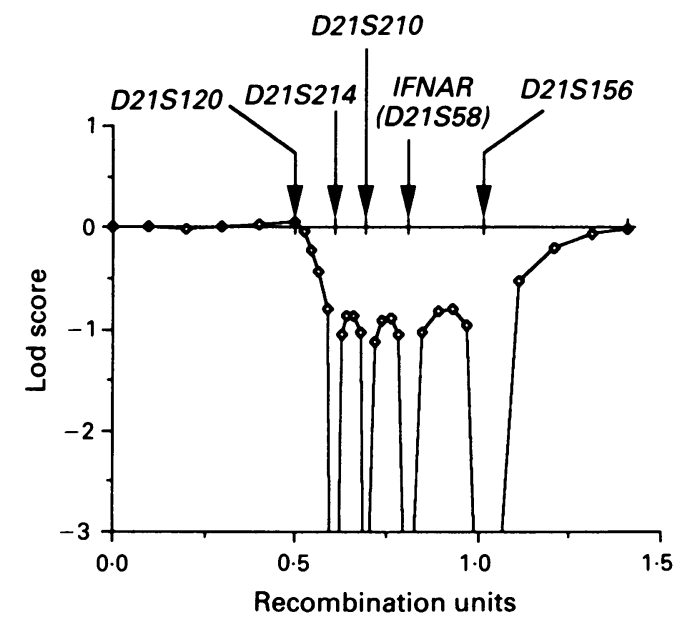

Figure Multipoint analysis of chromosome 21 loci in familial amyotrophic lateral sclerosis.

obtained with D21S120. Multipoint analysis was performed using the program LINKMAP (LINKAGE version 5.1). ${ }^{2}$ The genetic distances between the markers were derived from a published genetic linkage map of chromosome $21 .^{3}$ Multipoint analysis indicated significant exclusion of the FALS locus from a genetic distance of approximately $4 \mathrm{cM}$ around D21S214, $3 \mathrm{cM}$ around D21S210, $6 \mathrm{cM}$ around $I F N A R$, and $13 \mathrm{cM}$ around $D 21 S 156$ (figure). Siddique et $a l^{1}$ estimated that $55 \%$ of FALS families showed linkage to chromosome 21 , but using a test of heterogeneity, HOMOG version $2 \cdot 8,{ }^{4}$ we found no evidence of heterogeneity. In conclusion, we were unable to show a linkage between $F A L S$ and chromosome 21 markers close to the APP locus, $I F N A R$ and D21S156 (21q22.3) which flank the FALS locus identified by Siddique et al. ${ }^{1}$ No positive location scores were obtained around the previously reported FALS locus (21q22.1-q22.).

This project was financed by a grant from the MNDA.

1 Siddique T, Figlewicz DA, Pericak-Vance MA, et al. Linkage of a gene causing familial amyotrophic lateral sclerosis to chromosome 21 and evidence of genetic-locus heterogeneity. $N$ Engl f Med 1991;324:1381-4.

2 Lathrop GM, Lalouel JM, Julier C, Ott J. Multilocus linkage analysis in humans; detection of linkage and estimation of recombination. Am $\mathcal{F}$ Hum Genet 1985;37:48298.

3 Petersen MB, Slaugenhaupt SA, Lewis JG, Warren AC, Chakravarti A, Antonarakis SE. A genetic linkage map of 27 markers on chromosome 21. Genomics 1991;9:407-19. 4 Ott J. Analysis of human genetic linkage. Baltimore: Johns Hopkins University Press, 1985. 